\title{
Handling Water through Irrigation Watershed Management for Coping with Stream Pollution Dilution in Phetchaburi River, Thailand
}

\author{
Soulivanh Voravong ${ }^{1}$, Kasem Chunkao ${ }^{1,2}$ \& Surat Bualert ${ }^{1}$ \\ ${ }^{1}$ Department of Environmental Science, Faculty of Environment, Kasetsart University, Bangkok, Thailand \\ ${ }^{2}$ The King's Royally Initiated Laem Phak Bia Environmental Research and Development Project, Laem Phak \\ Bia Sub-District, Ban Laem District, Phetchaburi Province, Thailand \\ Correspondence: Kasem Chunkao, Department of Environmental Science, Faculty of Environment, \\ Kasetsart University, Bangkok 10900, Thailand. Tel: 66-2579-2116. E-mail: ecksc@ku.ac.th
}

Received: March 28, 2014

Accepted: June 11, $2014 \quad$ Online Published: June 30, 2014

doi:10.5539/mas.v8n4p195

URL: http://dx.doi.org/10.5539/mas.v8n4p195

\begin{abstract}
The research was aimed to find means how to handle water at Phetchaburi diversion dam for coping with stream pollution in Phetchaburi River through irrigation watershed management. There eight sampling points for collecting water samples since the year of 2002 to 2013 for analyzing water quality in relation to release water flow in consecutive velocity of $22.4,100$, and $377 \mathrm{~m}^{3} / \mathrm{s}$ in order to obtain the better diluted stream water. Accordance with the same trends of water quality indicators, this study was taken in BOD and DO as the representatives for determining the role of flow velocity in dilution capability. The results found that the BOD were gradually decreased from Phetchaburi diversion dam all the way to agricultural zone and jumping up during passing the city zone, and still jumping up in estuarine zone. Whenever the BOD decreases, the DO values were also decreased because of bacterial organic digestion process occurring while it flows except very high flow velocity. The flow velocity not more than $30 \mathrm{~m}^{3} / \mathrm{s}$ is recommended to release from Phetchaburi diversion dam for eliminating stream pollution by dilution process.
\end{abstract}

Keywords: Phetchaburi River, handling water, irrigation watershed management, stream pollution dilution

\section{Introduction}

Stream pollution has been accepted as a big problem around the world for more than 50 years ago because the human settlement preferred to localize along with riverbanks rather than farthermost areas (LERD, 1999; LERD, 2000; Chu et al., 2010; PCD, 2010; LERD, 2011; Chunkao et al., 2012; LERD, 2012; PCD, 2013). Consequently, the household wastewater cannot be avoided to drain directly into river without any treatment technology that caused the water pollution in stream in situ of non-living things one way or another (Burnett et al., 2007; Wang et al., 2010). Lack of water consumption could be pronounced on waterworks, irrigation, industry, sea water intrusion, and recreation (Wang et al., 1978; Vagnetti et al., 2003; Wahla \& Kirkham, 2008). In principles, every water course has their own self-purification capacity in limit conditions of natural dissolved oxygen availability, the balance of organic matter inputs and rate of organic digestion processes as well as very dense population and natural disasters from heavy rain and floods (Robinson \& Maris, 1985; Cazelles et al., 1991; Randall \& Mulla, 2000; Pastel \& Richter, 2003; Vagnetti et al., 2003; Tanji et al., 2006; Wahla \& Kirkham, 2008; Srigate, 2009; Valipour et al., 2009; Wang et al., 2010; Rakthai, 2012). In reference to aforesaid issues, watershed management, which is defined as the environmental systems for managing water, has been initiated in order to relieve stream water quality problems down to at least to meet the desirable quality water for specific targets (Chunkao et al., 1981; Chu et al., 2010; Chunkao et al., 2010). In other words, there are some watersheds that specify its own management criteria for specific water yields (quantity, quality, and flow regime) but it is usually under the multiple use purposiveness for general public land areas as explained by Robinson and Maris (1985); Linsley et al. (1988); Cazelles et al. (1991); Tanji et al. (2006); However, Chunkao (2008); Valipour et al. (2009); Wang et al. (2010); Mangimbulude et al. (2012) and Kraus et al. (2014) described that the specific purpose in watershed management would be provided to serve needs of water managers in order to achieve the project goal without any delay of work program.

Irrigation watershed management is a tool not only managing unit area for sustainable water availability in stream but also for feeding in double-crop paddy fields in order to grow mainly rice, and also in another flatlands 
for planting vegetables, flowerers, medicinal plants, fruit trees, etc. (Chunkao et al., 1981; Chunkao, 2008). The key points on irrigation watershed management is to handle water yields in stream for maintaining optimum quantity, quality, and flow regime in order to ready-use for irrigating, self purifying, and aquatic animal and plant ecology in wet and dry seasons without lacking the desirable quality water flow (Chunkao, 1981; 2008; Liu et al. 2009; Kraus et al., 2014). Unluckily, most of rivers in the whole country has been changed the forested cover in headwater to become the cultivated and human settlement areas that causing the streams running dry in summer but high amount of excess water in wet season and turning to be flooded on flatlands as pointed out by Wang et al. (1978); Chunkao et al. (1981); Vagnetti et al. (2003); Burnet et al. (2007); Chunkao et al. (2008); Liu and Chen (2009); Wahla et al. (2008); Chu et al. (2010); PCD (2010); Chunkao et al. (2012); PCD (2013). For solving such problem, the storage dam construction could be the best tool for restoring the excess water of wet flow for distributing it in dry period to serve needs of all end users without happening water shortage. Thailand has been constructed storage dam in upland areas and diversion dam in lowland for draining stream water into paddy areas as the first choice. Then after, water flow in streams, rivers, and irrigation canals can be taken out for livestock, cultivated lands, industrial estates, community waterworks, and conditioning environment under permission of concerned government agencies and automatic public uses (Chunkao, 2008; PCD, 2010; PCD, 2012).

Phetchaburi River basin is mostly comprised of double-crop paddy field for rice growing even the drought period the water has to be drained out to these areas. Certainly, stream flow of Phetchaburi River has to be decreased until it cannot be utilized to dilute the wastewater from communities along riverbanks, and agricultural activities that making stream pollution in summer period. Moreover, the diversion dam of Kaeng Krachan storage dam, named as Phetchaburi diversion dam, has its own function not only diverting water to feed on mainly paddy fields in lowlands and to feast the river flow but also providing waterworks of well-known Hua Hin tourist area. In other words, the stream pollution of Phetchaburi River would be occurred for some period of time due to water from Phetchaburi diversion dam that concerning with only to paddy fields in Phetchaburi province and Hua Hin the tourism area (Chunkao, 2008). Conceptually, the Phetchaburi river pollution should not be occurred if the Phetchaburi diversion dam managing unit was well planned for distributing water to feed the double-crop paddy field, Hua Hin Waterworks, and Phetchaburi River for maintaining sustainable aquatic ecosystems under optimized benefits each other. In the same manner, wastewater from households, communities, municipals, industries, livestock, and cropping areas has to be treated before draining into Phetchaburi River (Valipour et al., 2009; PCD, 2010; Chunkao et al., 2012; PCD, 2013).

Naturally, the pollutants of stream pollution are composed of organic matter as a major component, toxic and non-toxic chemicals, microorganisms, and gases which obtained from the point sources of communities, industries, livestock, croplands, and transportation (Robinson and Maris 1985; Loomis et al., 2000; Vagnetti et al., 2003; Chen et al., 2008; Chunkao, 2010; PCD, 2013). There have been wastes discharging to the natural river about 1 million tons/day from communities, industries, and agriculture (WHO, 2010) that caused not only stream pollution but also the outbreak of water-born diseases and following with human and biotic mortality as well (Chen et al., 2008; Chunkao, 2010; LERD, 2012). Besides, WHO and UNICEF (2010) reported that people died from natural water diseased contamination approximately 1.8 million people/day while Chen et al. (2009) informed the destruction of biotic biodiversities of freshwater species in aquatic ecosystems that affecting to human use values and life quality values in long term. In the effort to manage water to meet human needs, the needs of freshwater animal and plant species in ecosystems have largely been neglected, only if the water management method that having taken with care for controlling on water flow, wastewater treatment and soil erosion (Loomis et al., 2000). In theory, the ecological values, both structure and function, of watershed ecosystems are very necessary to aquatic habitats of animals, plants, and microorganisms when the water resources are utilized much more than its carrying capacity that making some difficult for self-recovery under nature-by-nature process (Chunkao, 2001; LERD, 1999, 2000, 2009, 2010, 2011, 2012). If the balance occurred between organic inputs and inorganic materials outputs which were equivalent to organic inputs to be kept in sustainability, the disappearance of stream pollution could not be known without using any scientific instruments. This would be remarkably stressed that the households as settled along the riverbanks found difficulty to look for the appropriated wastewater treatment devices because some houses are unlawful to take over the riverbanks and sometime inside the river. No doubt to say that the stream water has to be polluted after producing wastewater from daily lifestyles in various activities. Installing wastewater treatment technology could be helpful to restrain on both solid and liquid wastes (LERD, 1999, 2000, 2010, 2011, 2012).

In water resources deterioration point of views, the affected aquatic ecology as seen in Phetchaburi River, its analyzing biochemical oxygen demand (BOD) concentration found the averaged value of $7.36 \mathrm{mg} / \mathrm{l}$ along the 
river (LERD, 2010; 2012) which was higher than surface water quality standard in type 5 , as identified by Pollution Control Department (PCD, 2010, 2012), due to much more water uses for agricultural production, consumption and industrial sectors that making small amount of water flow to remain in Phetchaburi river. Meanwhile, there were wastes discharging from land uses for agriculture and community activities to this river that might be taken in account with the ecological effects and environmental problems. Nowadays, it is still neglected on the operation on managing environment and ecosystems of Phetchaburi River that may be destructed on the aquatic organisms for their habitats in the future (Penha-Lopes et al., 2011). If so, the Phetchaburi River is expected to become area of disease spreading sources to deteriorate on sanitation, health and life quality to the people whom are living both sides of Phetchaburi River.

It is acceptable that the prohibition is impossible for draining household wastewater into natural rivers from households and communities which are located along riverbanks owing to inherit in Thai culture since old generation. Only if, the pollutants in stream polluting condition have to decrease down to standards under the dilution process. Generally, the dilution process is another treatment technology which relies on good enough water quantity and quality as dilutor from upstream and headwater in order to decrease the contaminant concentration in stream pollution. Normally, rainwater in wet season plays vital role in diluting to the polluted water in the river that is why water quality indicators in wet flow are lower than the values in dry flow. Owing to head watersheds to be degenerated for more 50 years, it has been caused a lot of streams becoming ephemeral and intermittent which ran dry immediately and 2-3 months after rain falling, respectively, around the Kingdom of Thailand.

In principles, the perennial stream is defined as the watercourse that exists continuously water flow from dense forested cover in highland as headwater all year round, no matter wet or dry seasons (Chunkao, 2008). The latest stream plays a vital role in controlling the balance between rate of organic matter inputs and exactly the rate of organic digestion process, called as self purification, which are nourished the inorganic materials in form of algae nutrients for feeding herbivore fishes as for carnivore food in terms of food chain concept. Zero-growth-rate fishes harvesting is very necessary for sustaining aquatic lives of all riverine ecosystems and also reservoir for storing water supply otherwise the water may be turned green of dense algae population and polluted in consequences. Actually, there are a lot of storage reservoirs at the time which are presumably represented as man-made reservoirs for keeping excess water in wet period and ready to utilize in dry period and during water shortage period (Linsley et al., 1988). In fact, the storage dam plays a significant role in conformity with natural head watershed in terms of water feeding the streams/rivers for continuity of streamflow. If so, it is really needed the effective plan for handling water flow to dilute the stream pollution to decrease any high concentration of some toxic contaminants (Chunkao, 2008).

Presumably, the contaminated toxicants in Phetchaburi river can be treated by draining more quantitative and better qualitative water from Kaeng Krachan storage reservoir through Phetchaburi diversion dam for not only releasing water to feed double-crop paddy fields, and Hua Hin tourist city but also for feeding Phetchaburi river in order to dilute organic and in-organic wastes from human settlement along the riverbanks. Besides, the dilution process is expected to receive the effective measures of handling water flow from Phetchaburi diversion dam in both wet and dry periods.

\section{Characterization of Phetchaburi Watershed}

Phetchaburi irrigation watershed is located only in Phetchaburi province, the central part of Thailand, between the latitude $12^{\circ} 42^{\prime}$ to $13^{\circ} 38^{\prime} \mathrm{N}$ and longitude $99^{\circ} 10^{\prime}$ to $100^{\circ} 08^{\prime} \mathrm{E}$, the highest elevation of $1,202 \mathrm{~m} \mathrm{MSL}$ down to the outlet at the Gulf of Thailand by covering total area of 5,692 sq. $\mathrm{km}(1,423,000$ acres) including reservoir 46.5 sq.km (11,625 acres). The total area of watershed has been classified into forest $51 \%$, upland cropping $31 \%$, paddy rice field $13 \%$, community $4.51 \%$, water sources $4 \%$, and others $1 \%$ as determined by LDD (2011). For convenience of study, the watershed can be divided into headwater (2,210 sq.km), middle land (1,324 sq.km), lowland (1,028 sq.km), and sea coast (1,040 sq.km) but it was taken in 3 sections in the concept of riverine systems from lower Phetchaburi diversion dam to the outlet, that is, agriculture, city, and estuarine zones. There are 4 sub-watersheds which are named as Huai Banklai, Huai Mae Pradon, Huai Pak, and Huai Mae Prachan streams as seen in Figure1. In fact, the headwater is located inside of Kaeng Krachan National Park about 2,915 sq.km which has been established in June 1981 while Kaeng Krachan dam together with reservoir capacity 710 MCM in 1966.

Two sub-watersheds of Phetchaburi watershed, Huai Mae Pradone and Huai Banklai, are naturally discharged the averaged surface water to the Kaeng Krachan reservoir 138.02 MCM/mo (ranging $57.10-223.41 \mathrm{MCM} / \mathrm{mo}$ ) excluding unaccountably quantitative amount of subsurface flow from saturated forested soil zone (Chunkao 
2008; Chunkao et al., 1981; Baver, 1968; Baver et al., 1972). Accordance with Kaeng Krachan storage dam has been constructed for mainly irrigation by using Phetchaburi diversion dam for distributing water to double-crop rice fields and another water-demand economic plants by Q1, Q2, and Q3 for paddy, Q4 for Phetchaburi river (about 80-km long from Phetchaburi diversion dam to river mouth), and Q5 for Hua Hin district (beach tour area) as shown in Figure 1. Actually, the water quantity is continuously released from Phetchaburi diversion dam to control flow regime of Phetchaburi River (Q4) and waterworks of Hua Hin district (Q5) under the demanded irrigated water to feed the paddy fields and also during water shortage. In terms of stream pollution, it is usually happened in dry period due to irrigate much more quantity to double-crop fields for growing rice. Consequently, Phetchaburi river becomes stream pollution for such period (November to early April) until the wet season comes (late April to October). However, the climatic characteristic of Phetchaburi watershed has been classified as tropical rainforest in higher elevation, particularly headwater area, and normal tropical zone as explained the details in Table 1.

It is acceptable that there are a lot of permanent settlement of communities, municipals, and households along the riverbanks of Phetchaburi River which has been functioned as point sources of organic wastes, toxic and non-toxic chemicals, oil and grease, debris, and microorganisms to deteriorated streamflow one way or another. The experiment of dilution process for better water quality control was possible to keep streamflow of Phetchaburi River clean enough to use for waterworks, households, and ecosystems servicing.

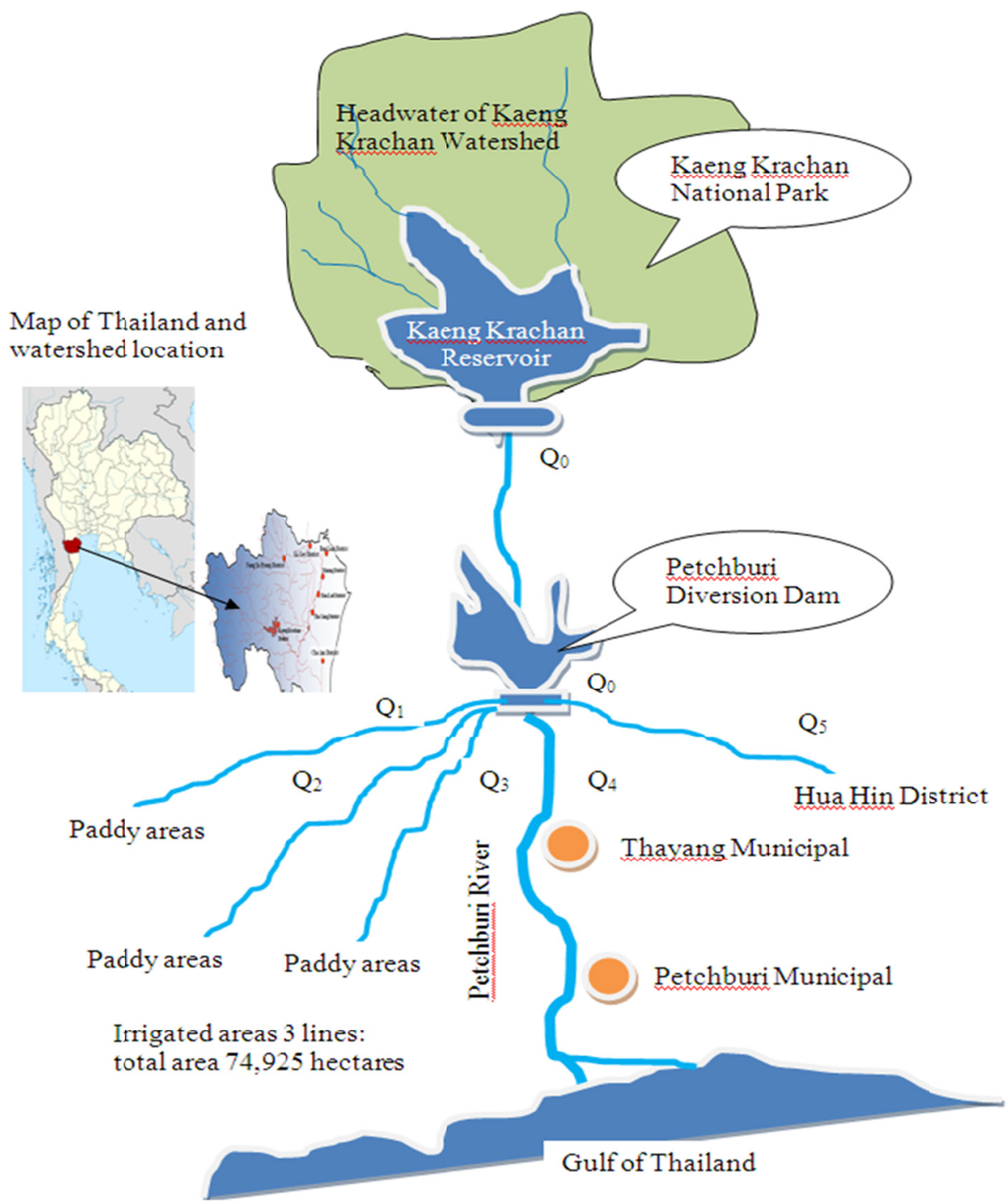

Figure 1. Location of Phetchaburi watershed including four streamlets for inflow water from Kaeng Krachan National Park as headwater through Kaeng Krachan reservoir to $r$ diversion dam before draining out to feed the five irrigation canals plus Phetchaburi River 
Table 1. General climatic characteristics of Phetchaburi watershed as taken in the period 1982-2008 for representing the normal phenomena at Kaeng Krachan dam site

\begin{tabular}{|c|c|c|c|c|c|c|c|c|c|c|c|c|c|}
\hline \multirow{2}{*}{ Items } & \multicolumn{4}{|c|}{ Summer } & \multicolumn{4}{|c|}{ Rainy Season } & \multicolumn{4}{|c|}{ Winter } & \multirow{2}{*}{ Year } \\
\hline & Feb. & Mar. & Apr. & May & Jun. & Jul. & Aug. & Sep. & Oct. & Nov. & Dec. & Jan. & \\
\hline \multicolumn{14}{|l|}{ Temperature(C) } \\
\hline Maximum & 33.1 & 34.2 & 3.5 & 36.1 & 35.6 & 35.6 & 35.4 & 34.8 & 33.9 & 33.6 & 33.3 & 33.1 & 34.5 \\
\hline Minimum & 19.4 & 21.2 & 23.5 & 24.3 & 24.2 & 23.7 & 24.1 & 23.5 & 22.6 & 20.1 & 17.0 & 17.3 & 21.7 \\
\hline Average & 26.9 & 28.3 & 29.5 & 29.6 & 29.3 & 28.9 & 29.0 & 28.4 & 27.9 & 27.1 & 25.7 & 25.8 & 28.0 \\
\hline \multicolumn{14}{|l|}{ Rainfall (mm) } \\
\hline Rain day & 1.0 & 2.7 & 3.5 & 10.5 & 12.3 & 13.7 & 14.9 & 16.1 & 16.9 & 6.4 & 1.4 & 0.9 & 100.2 \\
\hline Average rainfall & 100.0 & 918.3 & 893.0 & 2601.7 & 2406.3 & 2172.5 & 2406.9 & 4176.9 & 7065.6 & 2223.8 & 331.7 & 262.0 & 2129.9 \\
\hline \multicolumn{14}{|l|}{ Humidity (\%) } \\
\hline Average & 76.2 & 76.9 & 75.6 & 75.9 & 74.9 & 75.5 & 75.5 & 79.5 & 81.0 & 76.0 & 71.0 & 73.9 & 76.0 \\
\hline \multicolumn{14}{|l|}{ Evaporation } \\
\hline (mm/month) & 115.5 & 136.5 & 143.7 & 124.3 & 112.2 & 107.3 & 102.3 & 98.7 & 88.2 & 90.4 & 88.6 & 95.5 & 108.6 \\
\hline \multicolumn{14}{|l|}{ Wind (Knot) } \\
\hline Average speed & 3.6 & 5.0 & 4.1 & 2.7 & 2.1 & 1.9 & 1.8 & 1.3 & 1.2 & 1.4 & 1.6 & 1.8 & 2.4 \\
\hline Direction & $\mathrm{S}$ & $\mathrm{S}$ & $\mathrm{S}$ & $\mathrm{S}$ & $\mathrm{S}$ & $\mathrm{S}$ & S.SW & $\mathrm{S}$ & NW & NW & NW & NW & \\
\hline
\end{tabular}

Noted: $\mathrm{S}=$ South, $\mathrm{W}=$ West, $\mathrm{NW}=$ Northwest.

\section{Methodology}

\subsection{Water Quantity Measurement}

In principles of fluid mechanics, the streamflow discharge $(\mathrm{Q})$ is equivalent to multiply the cross-sectional area (A) by flow velocity of stream (V). The measured $\mathrm{Q}$ of the same stream is presumably equal to all measuring points in case of no inflow and no outflow, that is, A has to be inversely with V. In other words, the narrower stream causes the higher the flow velocity, in turn to make more and more momentum of stream discharge. The before statement is very necessary to understand in combining to dilution process that concerning with flow velocity and its quantity during in motion. So, Royal Irrigation Department has established the staff gages all the way of Phetchaburi River in order to obtain its discharge as well as its hydrograph that belonging to each sampling point (Linsley et al., 1988; Chunkao, 2008). In case of non-available staff gage, the current meter can be used for getting flow velocity together with measuring cross-sectional area in which the discharge can be calculated from 12-year period between 2002 -2013 at that point on Phetchaburi River as seen in Figure 2.

Unexpectedly, there were few days of high intensity rainfall occurring over the headwater, Kaeng Krachan National Park and downstream areas during 7-11 November 2013 that caused surface water flowing above reservoir capacity. Consequently, the Royal Irrigation Department had to drain out the excess stored water only along to Phetchaburi river, not to double-crop rice fields and Hua Hin district due to avoid the tangible and intangible losses. Because of excess water plus heavy rainfall, the occurrence of flood was spread over downstream all the way from the Phetchaburi diversion dam to watershed outlet at Ban Laem district, Phetchaburi province. Thus, Phetchaburi River was to support some toxic and non-toxic contaminants which were washed away from agricultural, villages, suburban, and urban areas by such overflowing water with the gravitational forces.

\subsection{Localization of Sampling Points}

Eight sampling points were purposively localized on Phetchaburi river under three sections of land use and land cover for agricultural zone (SW1, SW2, and SW3), Municipal zone (SW3, SW4, SW5, and SW6) and fishery zone (SW6, SW7, and SW8) as illustrated in Figure 2. It was observed during field study that there were some amount of in-between-zone inflow from natural streamlets (creeks) to the agricultural zone (SW1-SW3) than the municipal zone (SW3-SW6) which mostly obtains inflow from municipal sewerage and also rainwater, but rather very small amount of inflow than outflow in fishery zone (SW6-SW8) in estuarine reach. 


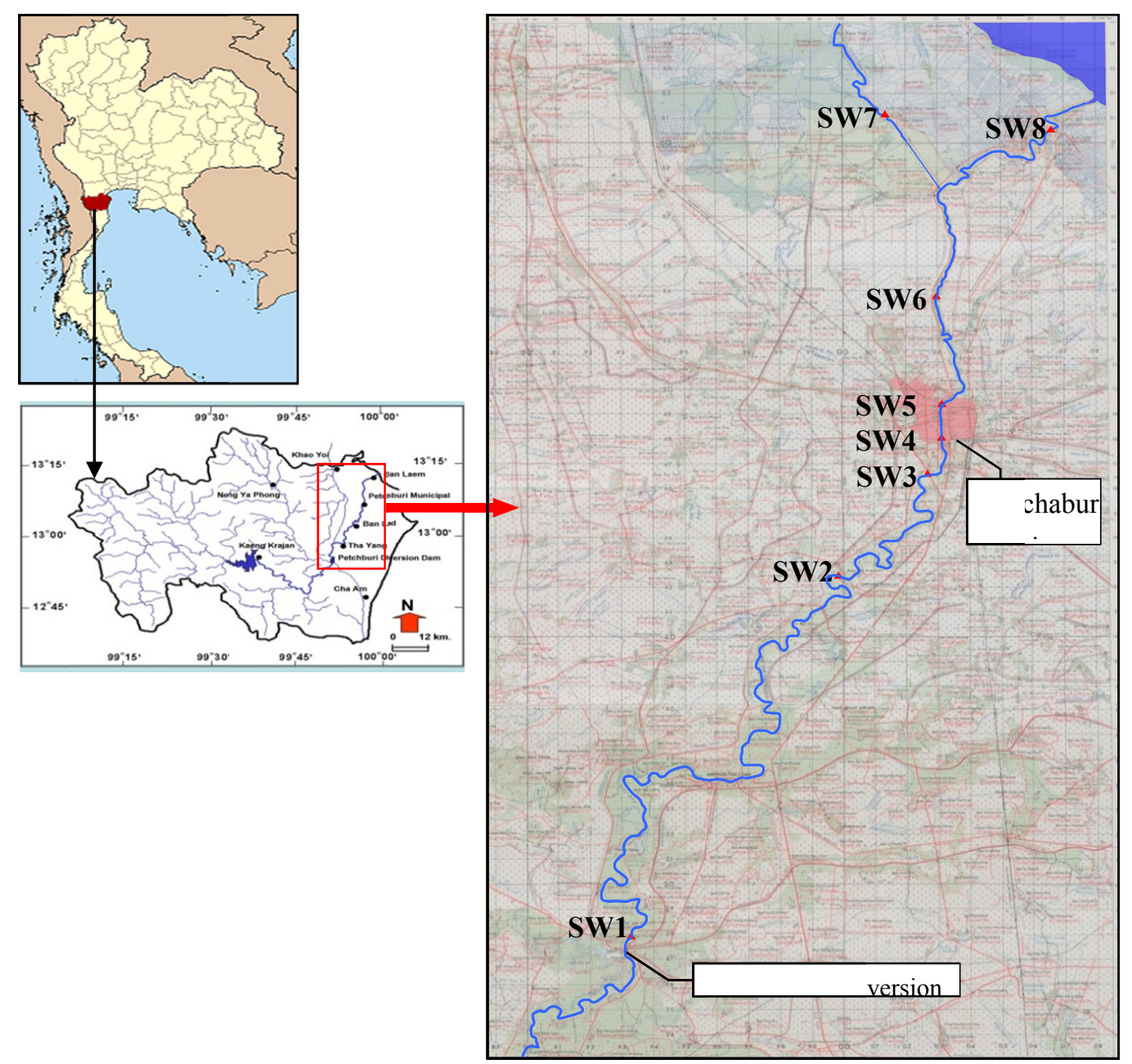

Figure 2. Locations of staff gages and water quality sampling points as established all the way from headwater to the outlet of Phetchaburi River

\subsection{Water Quality Collection and Analyzing}

Water samples were collected on each sampling point at 30-cm depth under the criteria of APHA.AWWA.WEF (1992), AWWA. APWA.WEF (1999); LERD (1999, 2000, 2010, 2011, 2012); Mathews and Richter (2007) for analyzing mainly BOD and DO (and also another indicators such as COD, TSS, salinity, pH, etc.) but using only for supporting factors in this research). Anyhow, the research is concentrated on normal, dry and wet flows in order to suit with the role in handling water for coping stream pollution dilution process for better water quality of Phetchaburi River from Phetchaburi diversion dam on the way to outlet at estuarine zone.

\section{Results and Discussion}

In general, the stream pollution of Phetchaburi River is usually occurred in both situations, very dry period and too much needs of water for growing rice. Aforesaid statement could be induced to handle water flow from Phetchaburi diversion dam to use for reduce the stream pollution condition through the dilution process. In other words, handling water from Phetchaburi diversion dam can be stressed as a key issue on water quality management Phetchaburi River for serving needs of people who lives along the riverbanks and remote communities as well as cultivated areas. The details of study will be presented in the following sections.

\subsection{Water Quantity and Flow Regime}

Naturally, the Phetchaburi irrigation watershed $(2,915$ sq.km) has received the averaged annual rainfall input approximately $1,750 \mathrm{~mm}$ by isohyetal and facet methods (Linsley et al., 1988; Chunkao, 2008), minimum 944.7 $\mathrm{mm}$ in downstream areas (from Kaeng Krachan reservoir) and maximum 2,335.0 $\mathrm{mm}$ to the highest point at $1,202 \mathrm{~m} \mathrm{MSL}$, which is equivalent to rainwater about 5,930 MCM per annum. In forested headwater (1,545 
sq.km) as located inside Kaeng Krachan National Park, the averaged annual rainfall input was determined about 2,230 $\mathrm{mm}$, then converting into rainwater approximately 7,480 MCM per annum. So, the total rainwater falling on the Phetchaburi watershed is equal to $13,410 \mathrm{MCM}$ per annum as the inflow to Kaeng Krachan reservoir for feeding double-crop paddy rice fields, fruit tree plantation, livestock, waterworks, households, and environmental purposes. For criterion of rainwater distribution by Royal Irrigation Department in Thailand, this amount of rainwater $(13,410 \mathrm{MCM})$ becomes to evaporated water $75 \%(10,057 \mathrm{MCM})$ and streamflow $25 \%$ $(3,353 \mathrm{MCM})$ which can be able to store about 20\% (671 MCM) otherwise it has to go down to the sea (Gulf of Thailand), especially in rainy season. For 12-year records, rainfall has been occurred over head watershed all-year round with more than 200 rainy days that make sure for continuous flow in Phetchaburi river without running dry. Unfortunately, the aforesaid statement happen only upstream areas (above Phetchaburi diversion dam) but it is not found out in dry period in downstream owing to overusing water from expanding cropping and housing areas. Therefore, handling water at Phetchaburi diversion dam is necessary to facilitate the streamflow throughout Phetchaburi River down to river mouth for eliminating saline intrusion after taking it for double-crop rice paddy fields and waterworks.

The total flow as measured at Phetchaburi diversion dam site was found $502.53 \mathrm{MCM} / \mathrm{yr}$ which included wet flow $359.89 \mathrm{MCM} / \mathrm{yr}(70 \%)$ and dry flow $142.07 \mathrm{MCM} / \mathrm{yr}(30 \%)$ as shown in Table 2. Owing to the Kaeng Krachan reservoir is holding the storage capacity of $710 \mathrm{MCM}$ but the actual storage can be either death or maximum levels depending on the rainstorm size (Linsley et al., 1988; Chunkao, 2008). In case of heavy rain, the water manager has to drain excessive inflow more than drying periods approximately 4 times such condition showing during 2002-2013 in Figure 3 and Table 2.

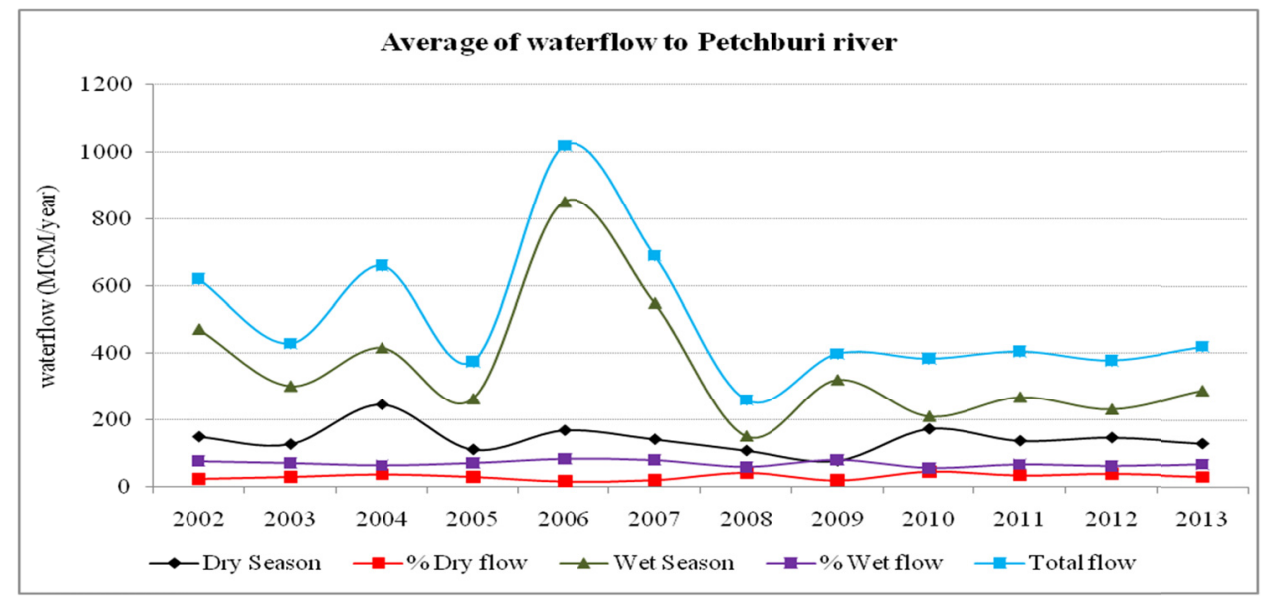

Figure 3. Wet, dry, and total flows as drained from Phetchaburi diversion dam to provide nourishment in downstream areas of Phetchaburi River in order to sustain the aquatic ecosystems servicing

Table 2. Water flow from Phetchaburi diversion dam to downstream of Phetchaburi River

\begin{tabular}{|c|c|c|c|c|c|}
\hline \multirow{2}{*}{ Year } & \multicolumn{2}{|c|}{ Dry Season } & \multicolumn{2}{|c|}{ Wet Season } & \multirow{2}{*}{$\begin{array}{c}\text { Total Flow } \\
\text { (MCM) }\end{array}$} \\
\hline & MCM & $\%$ Dry Flow & MCM & $\%$ Wet Season & \\
\hline 2002 & 148.95 & 24.01 & 471.47 & 75.99 & 620.42 \\
\hline 2003 & 127.02 & 29.67 & 301.02 & 70.33 & 428.04 \\
\hline 2004 & 244.27 & 37.02 & 415.62 & 62.98 & 659.89 \\
\hline 2005 & 111.04 & 29.68 & 263.13 & 70.32 & 374.17 \\
\hline 2006 & 167.76 & 16.47 & 850.61 & 83.53 & 1018.37 \\
\hline 2007 & 141.25 & 20.47 & 548.76 & 79.53 & 690.01 \\
\hline 2008 & 107.85 & 41.61 & 151.35 & 58.39 & 259.2 \\
\hline 2009 & 77.76 & 19.56 & 319.76 & 80.44 & 397.52 \\
\hline 2010 & 172.16 & 44.99 & 210.54 & 55.01 & 382.7 \\
\hline 2011 & 136.83 & 33.82 & 267.74 & 66.18 & 404.57 \\
\hline 2012 & 146.22 & 38.72 & 231.41 & 61.28 & 377.63 \\
\hline 2013 & 130.57 & 31.25 & 287.28 & 68.75 & 417.85 \\
\hline Average & 142.07 & 31.21 & 359.89 & 68.79 & 502.53 \\
\hline
\end{tabular}




\subsection{Accident Rainstorm and Flash Flood}

Experiences from field inventory found that the flow rate plays vital role in handling water from Phetchaburi diversion dam which is normally controlled under needs of water consumers. Based on flood problems along riverbanks and cities as well as municipals, flow rate can be classified as the averaging value of $15 \mathrm{~m}^{3} / \mathrm{s}$ (ranging $5-50 \mathrm{~m}^{3} / \mathrm{s}$ ) for normal flow, $75 \mathrm{~m}^{3} / \mathrm{s}$ (ranging $50-150 \mathrm{~m}^{3} / \mathrm{s}$ ) for warning flow, $200 \mathrm{~m}^{3} / \mathrm{s}$ (ranging $150-250 \mathrm{~m}^{3} / \mathrm{s}$ ) for risky flow, and more $250 \mathrm{~m}^{3} / \mathrm{s}$ for critical flow (Chunkao, 2010; Linsley et al., 1988; Loomis et al., 2000; Mangimbulude et al., 2012; Mathews \& Richter, 2007; Postel \& Richter, 2003; Tanji et al., 2006; Vagnetti et al., 2003; Wahla \& Kirkham, 2008; Wang et al., 1978; Wang et al., 2010). In other words, the normal flow which was drained from Phetchaburi Diversion dam could be neglected in flood along the stream banks, spot-area flood occurring under warning flow, small-low-flat land flooding from risky flow, and riverbank-settlement areas inducing flood from critical flow. This is why flash floods were accidentally occurred on 7-9 November 2013 because of heavy rainstorms striking all over the provinces of Phetchaburi, Prachuab Kirikhan, Ratchburi, and Samut Songkram that the Kaeng Krachan reservoir and Phetchaburi diversion dam had to release the excess rainwater with high flow rate up to $377 \mathrm{~m}^{3} / \mathrm{s}$. It would be emphasized that the heavy rainstorm provided plenty of clean water which is the best diluting water for reducing stream pollution likewise Phetchaburi River, especially in summer time and some water shortage period in wet season as well as the time for irrigating period on second crop growing.

\subsection{Water Quality and Concentration}

The research team of Royal LERD project office has collected monthly water samples for analyzing water quality indicators of streamflow in Phetchaburi River since 1995 after starting up the project 5 years in order to monitor the employment of oxidation pond and constructed wetland technologies for community wastewater treatment. The previous results have been somewhat satisfied to every water quality indicator but there were a big-worse problem for short period of time due to more amount of solid and dissolve organic substances as well as concerned indicators. However, the analyzed water quality indicators were shown in Table 3 which indicated the condition of existing indicators.

Table 3. Highlights of monthly water quality indicators in streamflow of Phetchaburi River as collected during 2002-2013

\begin{tabular}{|c|c|c|c|c|c|c|c|}
\hline \multirow{2}{*}{ Parameter } & \multirow{2}{*}{ Station } & \multicolumn{2}{|c|}{ Extreme dry Years in 2009} & \multicolumn{2}{|c|}{ Heavy Rainfall Years in 2010} & \multicolumn{2}{|c|}{ Coldest Years in 2011} \\
\hline & & Dry Period & Wet Period & Dry Period & Wet Period & Dry Period & Wet Period \\
\hline \multirow{8}{*}{$\begin{array}{l}\mathrm{NH}_{3} \\
(\mathrm{mg} / \mathrm{L})\end{array}$} & SW1 & $0.00-0.67$ & $0.111-1.72$ & $0.03-0.26$ & $0.03-0.19$ & $0.01-0.25$ & $0.03-0.13$ \\
\hline & SW2 & $0.03-0.78$ & $0.20-0.98$ & $0.02-0.41$ & $0.05-0.17$ & $0.01-0.24$ & $0.03-0.14$ \\
\hline & SW3 & $0.07-0.50$ & $0.13-0.83$ & $0.01-0.04$ & $0.04-0.23$ & $0.02-0.23$ & $0.04-0.16$ \\
\hline & SW4 & $0.03-0.48$ & $0.02-0.83$ & $0.02-0.31$ & $0.03-0.27$ & $0.02-0.18$ & 0.04-0.19 \\
\hline & SW5 & $0.04-0.56$ & $0.17-0.87$ & $0.00-0.31$ & $0.03-0.32$ & $0.03-0.25$ & $0.11-0.21$ \\
\hline & SW6 & $0.08-0.58$ & $0.04-1.06$ & $0.01-0.33$ & $0.03-0.23$ & $0.05-0.25$ & $0.12-0.24$ \\
\hline & SW7 & $0.17-1.67$ & $0.14-0.97$ & $0.03-3.90$ & $0.04-0.22$ & $0.06-0.45$ & $0.05-0.23$ \\
\hline & SW8 & $0.00-2.16$ & $0.15-1.67$ & $0.16-4.80$ & $0.12-0.34$ & $0.10-0.64$ & $0.13-0.58$ \\
\hline \multirow{8}{*}{$\begin{array}{l}\mathrm{NO}_{3} \\
(\mathrm{mg} / \mathrm{L})\end{array}$} & SW1 & $0.57-3.35$ & $0.48-2.06$ & $0.20-0.95$ & $0.47-1.59$ & $0.68-0.96$ & $0.58-1.00$ \\
\hline & SW2 & $0.57-2.75$ & $0.50-1.68$ & $0.16-0.99$ & $0.43-1.34$ & $0.71-0.88$ & $0.55-0.93$ \\
\hline & SW3 & $0.54-2.45$ & $0.46-1.49$ & $0.17-0.95$ & $0.43-1.81$ & $0.75-0.88$ & $0.55-0.93$ \\
\hline & SW4 & $0.50-2.36$ & $0.46-1.55$ & $0.20-0.99$ & $0.43-1.88$ & $0.74-0.90$ & $0.52-0.86$ \\
\hline & SW5 & 0.50 .2 .18 & $0.46-1.38$ & $0.18-1.04$ & $0.43-1.88$ & $0.68-0.90$ & $0.52-0.83$ \\
\hline & SW6 & $0.48-2.10$ & $0.50-2.10$ & $0.20-1.04$ & $0.41-1.88$ & $0.65-0.90$ & $0.52-0.79$ \\
\hline & SW7 & $9.88-46.50$ & $0.86-17.10$ & $0.21-42.10$ & $0.69-19.60$ & $10.05-22.30$ & $0.70-31.00$ \\
\hline & SW8 & $22.30-62.30$ & $0.79-54.95$ & $0.15-72.60$ & $0.86-33.80$ & $10.60-31.90$ & $0.75-38.00$ \\
\hline Total Coliform & SW1 & $140-3300$ & $350-7,900$ & $330-5,400$ & $80-5,400$ & $230-16,000$ & $130-5,400$ \\
\hline Bacteria & SW2 & $2,400-16,000$ & $490-16,000$ & $700-9,200$ & $2,400-5,400$ & $3,500-92,000$ & $430-16,000$ \\
\hline \multirow[t]{5}{*}{$(\mathrm{MPN} / 100 \mathrm{~mL})$} & SW3 & $2,200-16,000$ & $3,500-92,000$ & $5,400-16,000$ & $1,600-16,000$ & $9,200-35,000$ & $3,500-9,200$ \\
\hline & SW4 & $1,700-16,000$ & $490-92,000$ & $1,600-9,200$ & $2,800-24,000$ & $5,400-92,000$ & $5,400-16,000$ \\
\hline & SW5 & $940-16,000$ & $790-16,000$ & $1,600-16,000$ & $700-16,000$ & $9,200-92,000$ & $350-160,000$ \\
\hline & SW6 & $5,400-92,000$ & $330-54,000$ & $1,400-92,000$ & $5,400-24,000$ & $3,500-54,000$ & $5,400-92,000$ \\
\hline & SW7 & $3,500-35,000$ & $3,500-160,000$ & $5,400-22,000$ & $5,400-92,000$ & $3,500-54,000$ & $180-24,000$ \\
\hline
\end{tabular}




\begin{tabular}{lrrrrrrr} 
& SW8 & $3,300-9,200$ & $330-92,000$ & $5,400-16,000$ & $700-54,000$ & $540-92,000$ & $540-92,000$ \\
\hline Fecal & SW1 & $<2-110$ & $50-260$ & $80-1,100$ & $<1.8-2,200$ & $<1.8-1,400$ & $<1.8-260$ \\
Coliform & SW2 & $140-1,400$ & $110-1,800$ & $140-1,400$ & $170-2,200$ & $170-17,000$ & $70-2,200$ \\
Bacteria & SW3 & $260-2,200$ & $330-1,400$ & $1,100-2,200$ & $170-2,200$ & $330-9,400$ & $330-1,700$ \\
$($ MPN/100mL) & SW4 & $140-1,700$ & $70-7,000$ & $170-1,100$ & $170-2,200$ & $330-11,000$ & $260-2,200$ \\
& SW5 & $110-5,400$ & $90-2,200$ & $340-2,200$ & $110-2,800$ & $1,700-9,400$ & $170-22,000$ \\
& SW6 & $140-2,800$ & $80-11,000$ & $170-28,000$ & $340-2,800$ & $220-17,000$ & $170-3,400$ \\
& SW7 & $140-2,200$ & $140-94,000$ & $330-1,100$ & $140-9,400$ & $170-17,000$ & $80-2,700$ \\
& SW8 & $260-1,700$ & $<2-14,000$ & $120-2,200$ & $<1.8-3,400$ & $33-22,000$ & $270-4,900$ \\
\hline
\end{tabular}

Table 3. (Cont'd)

\begin{tabular}{|c|c|c|c|c|c|c|c|}
\hline \multirow{2}{*}{ Parameter } & \multirow{2}{*}{ Station } & \multicolumn{2}{|c|}{ Extreme dry Years in 2009} & \multicolumn{2}{|c|}{ Heavy Rainfall Years in 2010} & \multicolumn{2}{|c|}{ Coldest Years in 2011} \\
\hline & & Dry Period & Wet Period & Dry Period & Wet Period & Dry Period & Wet Period \\
\hline Water temp & SW1 & $25.8-28.3$ & $25.4-30.0$ & $26.9-29.2$ & $27.8-30.9$ & $26.6-30.3$ & $27.8-31.1$ \\
\hline \multirow[t]{7}{*}{$\left({ }^{\circ} \mathrm{C}\right)$} & SW2 & $27.4-31.7$ & $24.9-30.0$ & $26.9-32.2$ & $28.2-31.5$ & $27.1-30.3$ & $27.5-32.0$ \\
\hline & SW3 & $28.5-32.5$ & $25.5-32.5$ & $27.3-30.3$ & $28.7-31.7$ & $26.6-30.2$ & 27.4-32.1 \\
\hline & SW4 & $28.5-34.1$ & $26.0-30.5$ & $27.5-30.7$ & $28.6-31.9$ & $26.9-30.6$ & $27.4-32.2$ \\
\hline & SW5 & $28.4-33.0$ & 26.4-31.0 & $27.7-31.1$ & $28.8-32.2$ & $27.0-31.2$ & $27.7-31.9$ \\
\hline & SW6 & $28.8-32.5$ & $26.4-31.0$ & $27.6-31.0$ & $28.6-32.3$ & $27.0-31.0$ & $27.5-32.3$ \\
\hline & SW7 & $28.3-32.9$ & $25.7-31.7$ & $27.5-31.5$ & $29.0-32.5$ & $27.4-31.6$ & $27.3-32.3$ \\
\hline & SW8 & $27.2-33.7$ & $25.7-32.7$ & $26.7-31.7$ & $27.4-33.0$ & $26.5-32.1$ & $27.4-33.0$ \\
\hline \multirow[t]{8}{*}{$\mathrm{pH}$} & SW1 & $7.7-8.1$ & $7.5-8.2$ & $6.8-7.8$ & $6.8-8.0$ & $6.8-8.1$ & $7.2-8.0$ \\
\hline & SW2 & $7.3-7.9$ & $6.6-8.1$ & $6.3-7.5$ & $6.8-8.0$ & $6.8-7.5$ & $7.1-7.5$ \\
\hline & SW3 & 7.6-7.9 & $6.7-7.7$ & $6.9-7.6$ & $6.7-8.0$ & $6.8-7.5$ & $6.9-7.5$ \\
\hline & SW4 & $7.4-8.2$ & $6.7-7.6$ & $6.9-7.6$ & $6.8-7.9$ & $6.9-7.7$ & $6.8-7.6$ \\
\hline & SW5 & $7.6-8.3$ & $6.3-7.6$ & $6.9-7.5$ & $7.0-7.8$ & $6.9-7.9$ & $7.0-8.3$ \\
\hline & SW6 & $7.9-8.4$ & $6.6-7.7$ & $7.2-8.0$ & $7.0-8.3$ & $7.1-8.0$ & $7.0-8.4$ \\
\hline & SW7 & $6.9-7.5$ & $6.4-7.3$ & $6.5-7.1$ & $6.9-7.4$ & $7.1-7.5$ & $7.0-7.4$ \\
\hline & SW8 & $6.4-7.4$ & $6.4-7.1$ & $6.7-6.9$ & $6.9-7.2$ & $7.1-7.5$ & $7.0-7.4$ \\
\hline $\mathrm{EC}$ & SW1 & $113-128$ & $81-122$ & $102-266$ & $102-277$ & $128-159$ & $80-271$ \\
\hline \multirow[t]{7}{*}{$(\boldsymbol{\mu} \mathrm{S} / \mathrm{cm})}$. & SW2 & $121-145$ & $76-163$ & $120-248$ & $109-229$ & $136-185$ & $89-219$ \\
\hline & SW3 & $129-182$ & $76-167$ & $121-249$ & $108-233$ & $79-194$ & $92-221$ \\
\hline & SW4 & $122-188$ & $78-172$ & $120-248$ & $109-236$ & $148-203$ & $93-220$ \\
\hline & SW5 & $122-187$ & $78-195$ & $122-244$ & $110-237$ & $153-210$ & $94-223$ \\
\hline & SW6 & $125-195$ & $77-195$ & $124-244$ & $111-234$ & $156-219$ & $98-223$ \\
\hline & SW7 & $2,820-27,200$ & $157-15,020$ & $9,090-21,300$ & $360-11,370$ & $3,890-24,400$ & $179-3,500$ \\
\hline & SW8 & $10,240-39,600$ & $354-17,140$ & $7,460-35,100$ & $444-21,300$ & $5,930-18,250$ & $227-25,600$ \\
\hline TDS & SW1 & $56-85$ & $46-132$ & $68-178$ & $68-150$ & $84-104$ & $53-142$ \\
\hline \multirow[t]{7}{*}{$(\mathrm{mg} / \mathrm{L})$} & SW2 & $61-108$ & $51-108$ & $80-166$ & $73-153$ & $90-121$ & $59-143$ \\
\hline & SW3 & $64-122$ & $55-111$ & $80-166$ & $72-155$ & $96-129$ & $61-145$ \\
\hline & SW4 & $66-124$ & $52-114$ & $80-166$ & $72-157$ & $98-132$ & $61-144$ \\
\hline & SW5 & $66-124$ & $52-118$ & $82-162$ & $73-158$ & $100-141$ & $62-146$ \\
\hline & SW6 & $68-131$ & $51-121$ & $83-162$ & $74-156$ & $103-146$ & $62-146$ \\
\hline & SW7 & $3,840-23,229$ & $104-4,016$ & $7,272-17,040$ & $240-6,424$ & $3,112-19,520$ & $118-2,800$ \\
\hline & SW8 & $5,080-34,452$ & $236-15,928$ & $5,968-28,080$ & $296-17,040$ & $4,744-24,800$ & $150-9,712$ \\
\hline
\end{tabular}

Note. Extreme dry Years, Heavy Rainfall Years and Coldest Years were base on statistic of Phetchaburi Meteorological Station between 2005 to 2013 .

- Dry Period is December-April and Wet Period is May-November.

- SW1-SW3 is agricultural zone, SW4-SW6 is municipal zone and SW7-SW8 is estuarine zone.

\subsection{Dilution Process and Handling Water}

All water quality indicators as presented in Table 3 were directed the same way in terms of the existing 
conditions of stream pollution in Phetchaburi River for the past analysis on physical, chemical, and biological quality water. For building understandability, the study team made decision to take in BOD (biological oxygen demand) and DO (dissolved oxygen) by sampling during the occurrence of heavy rainstorm in order to compare with previous works as the same as urgent needs of water for rice growing and drought. Thus, the previous data and unexpected heavy rainstorm during 7-9 November 2013 were taken in analyzing the handling water for dilution process for coping with stream pollution of Phetchaburi river which the values of water quality were intentionally measured the indicators such as temperature, $\mathrm{pH}$, DO (Dissolved Oxygen), TDS (Total Dissolved Solid), EC (Electrical Conductivity), salinity, BOD, (Biological Oxygen Demand), nitrate, ammonia, TCB (Total Coliform Bacteria), and FCB (Fecal Coliform Bacteria) as illustrated in Table 4 and Figure 4.

Table 4. Water quality of Phetchaburi river in relation to streamflow velocity as sampled at consecutive measuring points for three zone of agricultural zone (SW1, SW2, SW3), municipal zone (SW3, SW4, SW5, SW6) and fishery zone (SW6, SW7, SW8)

\begin{tabular}{|c|c|c|c|c|c|c|c|c|c|}
\hline \multirow[t]{2}{*}{ Indicators } & \multirow[t]{2}{*}{ Q) $\mathrm{m}^{3} / \mathrm{s}($} & \multicolumn{8}{|c|}{ Station of sample water point along Phetchburi River } \\
\hline & & SW1 & SW2 & SW3 & SW4 & SW5 & SW6 & SW7 & SW8 \\
\hline Tempe & 22.4 & 29.6 & 29.6 & 30.0 & 29.6 & 29.8 & 29.8 & 30.2 & 30.2 \\
\hline \multirow[t]{2}{*}{)$^{\circ} \mathrm{C}($} & 100 & 28.1 & 27.5 & 27.8 & 27.8 & 27.8 & 27.9 & 28.8 & 28.7 \\
\hline & 377 & 27.7 & 27.6 & 27.6 & 25.0 & 26.4 & 27.2 & 26.7 & 27.5 \\
\hline \multirow[t]{3}{*}{$\mathrm{pH}$} & 22.4 & 7.6 & 7.5 & 7.4 & 7.4 & 7.6 & 7.7 & 7.3 & 7.3 \\
\hline & 100 & 7.3 & 7.8 & 7.9 & 7.9 & 7.9 & 7.8 & 7.8 & 8.0 \\
\hline & 377 & 7.9 & 7.9 & 7.9 & 7.7 & 7.6 & 7.8 & 7.6 & 7.7 \\
\hline DO & 22.4 & 3.2 & 2.9 & 2.9 & 2.8 & 2.5 & 2.6 & 1.1 & 0.2 \\
\hline \multirow[t]{2}{*}{ )mg/L( } & 100 & 6.5 & 6.0 & 5.2 & 5.5 & 5.2 & 5.2 & 5.2 & 4.4 \\
\hline & 377 & 5.8 & 5.7 & 5.9 & 6.3 & 6.1 & 5.7 & 5.7 & 5.1 \\
\hline
\end{tabular}

Table 4. (Cont'd)

\begin{tabular}{|c|c|c|c|c|c|c|c|c|c|}
\hline \multirow[t]{2}{*}{ Indicators } & \multirow[t]{2}{*}{ Q) $\mathrm{m}^{3} / \mathrm{s}($} & \multicolumn{8}{|c|}{ Station of sample water point along Phetchburi River } \\
\hline & & SW1 & SW2 & SW3 & SW4 & SW5 & SW6 & SW7 & SW8 \\
\hline BOD & 22.4 & 1.5 & 2.0 & 1.8 & 2.7 & 1.8 & 2.7 & 3.8 & 4.1 \\
\hline \multirow[t]{2}{*}{) $\mathrm{mg} / \mathrm{L}($} & 100 & 2.9 & 4.9 & 2.5 & 2.2 & 2.4 & 2.9 & 1.6 & 4.4 \\
\hline & 377 & 4.0 & 3.0 & 2.9 & 3.6 & 2.9 & 2.6 & 3.3 & 2.3 \\
\hline TDS & 22.4 & 121 & 129 & 121 & 120 & 121 & 122 & 566 & 2,544 \\
\hline \multirow[t]{2}{*}{ )mg/L( } & 100 & 160 & 169 & 177 & 168 & 168 & 170 & 170 & 215 \\
\hline & 377 & 144 & 135 & 134 & 136 & 136 & 134 & 143 & 205 \\
\hline $\mathrm{EC}$ & 22.4 & 184 & 195 & 183 & 183 & 184 & 186 & 858 & 3,180 \\
\hline \multirow[t]{2}{*}{)$\mu \mathrm{s} / \mathrm{cm} .($} & 100 & 239 & 253 & 253 & 251 & 250 & 252 & 255 & 320 \\
\hline & 377 & 214 & 201 & 199 & 206 & 203 & 200 & 213 & 306 \\
\hline $\mathrm{NO}_{3}-\mathrm{N}$ & 22.4 & 0.62 & 0.70 & 0.68 & 0.67 & 0.67 & 0.70 & 0.59 & 5.30 \\
\hline \multirow[t]{2}{*}{) $\mathrm{mg} / \mathrm{L}($} & 100 & 1.20 & 1.33 & 1.36 & 1.35 & 1.35 & 1.37 & 1.37 & 1.40 \\
\hline & 377 & 0.67 & 0.73 & 0.76 & 0.74 & 0.74 & 0.82 & 0.78 & 0.72 \\
\hline $\mathrm{NH}_{3}-\mathrm{N}$ & 22.4 & 0.04 & 0.05 & 0.06 & 0.08 & 0.12 & 0.13 & 0.13 & 0.22 \\
\hline \multirow[t]{2}{*}{ )mg/L( } & 100 & 0 & 0 & 0 & 0 & 0 & 0 & 0 & 0 \\
\hline & 377 & 0 & 0 & 0 & 0 & 0 & 0 & 0 & 0 \\
\hline $\mathrm{TCB}$ & 22.4 & 9,200 & 5,400 & 16,000 & 9,200 & 16,000 & 9,200 & 9,200 & 5,400 \\
\hline \multirow[t]{2}{*}{ )MPN/100mL( } & 100 & 5,400 & 9,200 & 16,000 & 3,500 & 2,800 & 5,400 & 9,200 & 5,400 \\
\hline & 377 & 92,000 & 9,200 & 54,000 & 92,000 & 16,000 & 5,400 & 9,200 & 5,300 \\
\hline $\mathrm{FCB}$ & 22.4 & 1,800 & 1,700 & 2,800 & 330 & 2,200 & 230 & 270 & 340 \\
\hline \multirow[t]{2}{*}{ )MPN/100mL( } & 100 & 1,100 & 1,100 & 1,800 & 270 & 170 & 330 & 940 & 330 \\
\hline & 377 & 17,000 & 1,400 & 17,000 & 11,000 & 2,200 & 700 & 790 & 490 \\
\hline
\end{tabular}




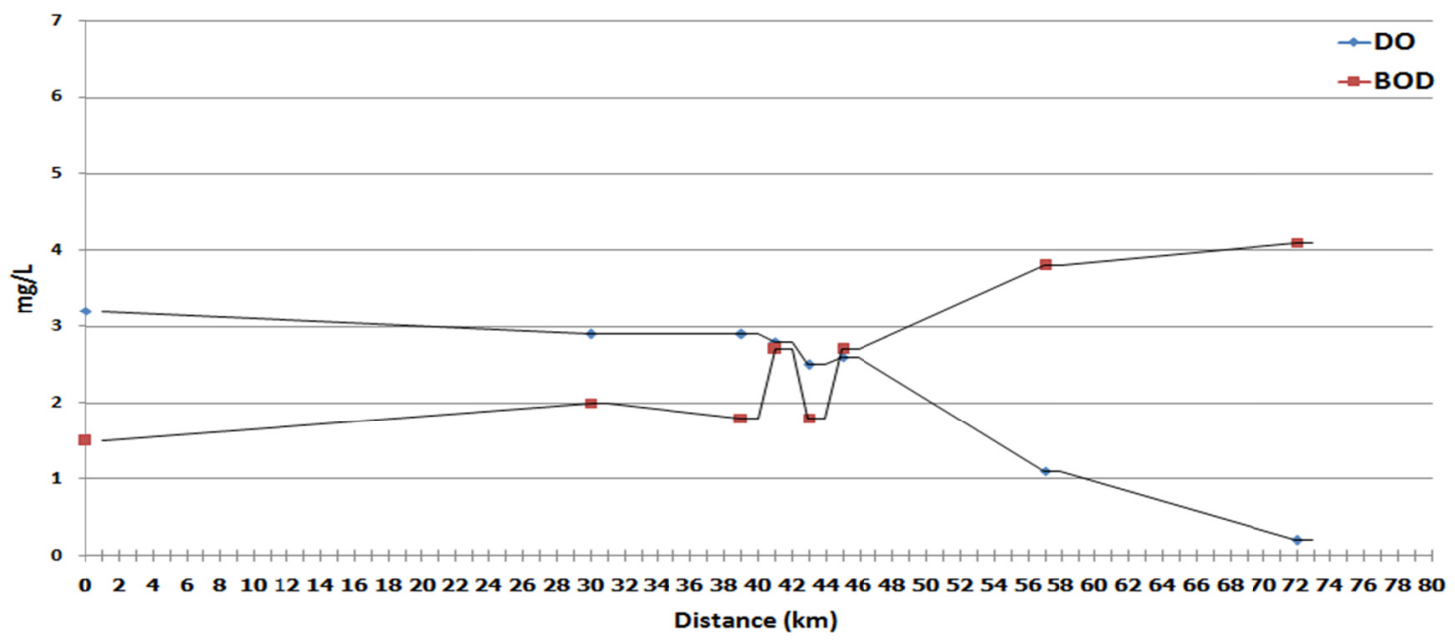

(a) Flow rate $22.4 \mathrm{~m}^{3} / \mathrm{s}$ (normal flow)

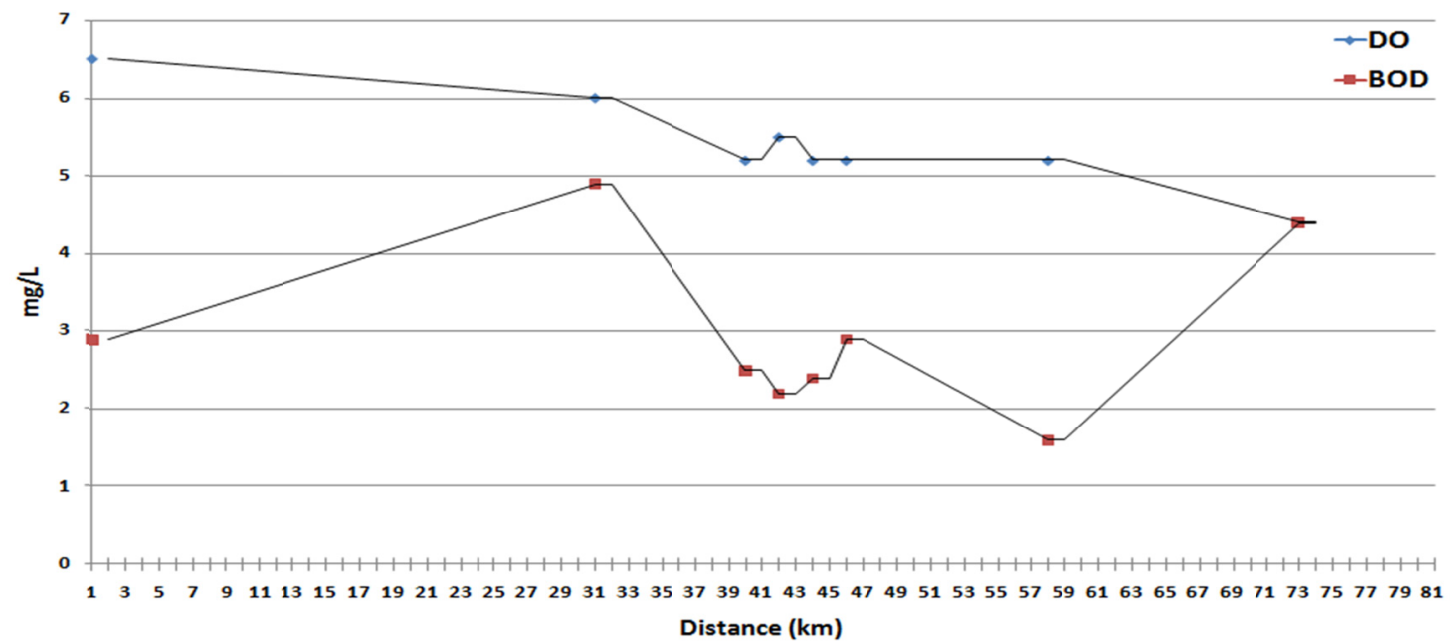

(b) Flow rate: $100 \mathrm{~m}^{3} / \mathrm{s}$ (flood flow)

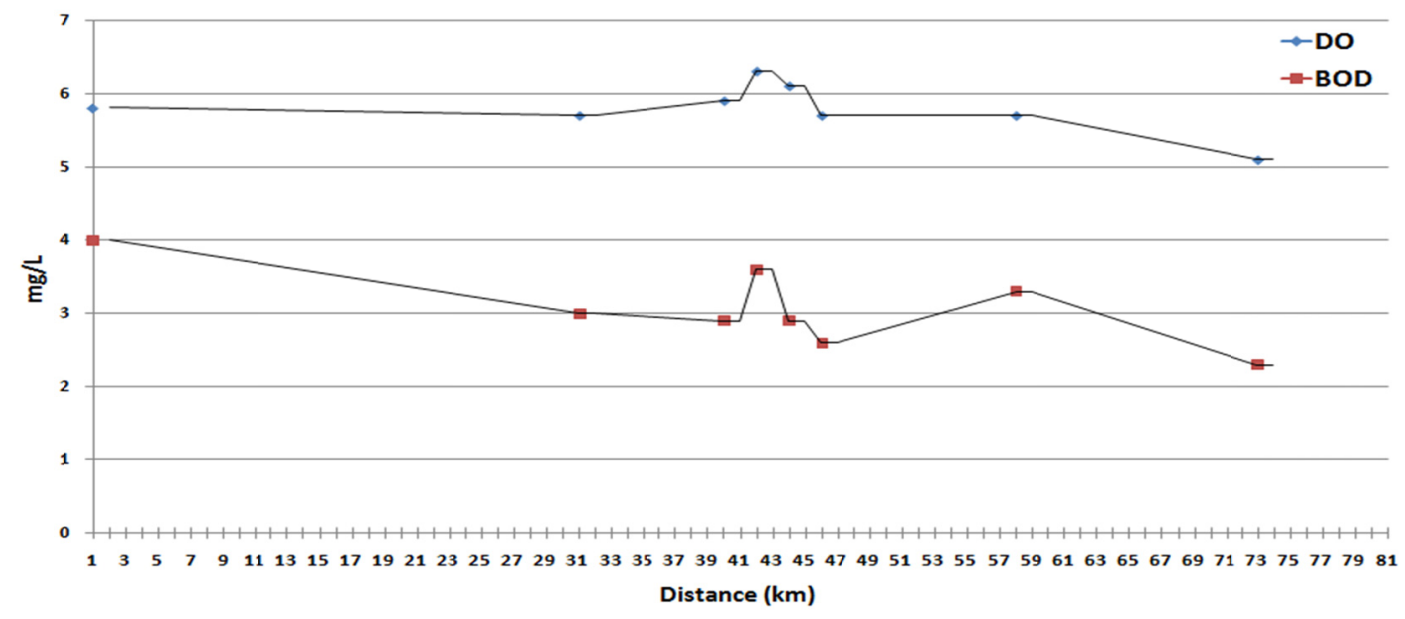

(c) Flow rate: $377 \mathrm{~m}^{3} / \mathrm{s}$ (flood flow)

Figure 4. Relationship between streamflow velocity and the values of BOD and DO along the sampling points as localized on various distance from Phetchaburi diversion dam throughout to outlet 
It is observed that all indicators for indicating the existing water quality in streamflow of Phetchaburi river did not look like polluted water even if the existence of some physical, chemical, and biological contaminants but their differences have been evident under the conditions of flow velocity as sampled at $22.4,100$, and $377 \mathrm{~m}^{3} / \mathrm{s}$. As stated before, BOD and DO were taken in representing water quality rather than the other indicators as shown in Table 3 and Figure 4. For normal flow $\left(22.4 \mathrm{~m}^{3} / \mathrm{s}\right)$, the values of BOD in drained water from Phetchaburi diversion dam were gradually increased and opposite to DO because they were getting close to the denser population areas which polluted organic wastes and other contaminants becoming more and more, while DO was used for bacterial organic digestion processes (Cazelles et al., 1991; Chen et al., 2008; Penha-Lopes et al., 2011; Chunkao et al., 2012). The situation became worse when the said mass flow got close to the city zone (municipal zones) at the distance range between $\mathrm{km} \mathrm{39th} \mathrm{to} \mathrm{km} 45$ th by increasing BOD and decreasing DO. Then after, BOD was rapidly increased while DO drastically decreased in estuarine zone at $\mathrm{km} 72 \mathrm{nd}$ according to two causes: firstly, this river reach is not only obtained organic and inorganic contaminants from upstream municipals but also still high dense population to pollute the stream water; and the second, the estuarine zone is consisted of saline water which plays significant role in inhibiting bacterial organic digestion process but more DO are utilized as energy for the said process (Wang et al., 1978; Vagnetti et al., 2003; Tanji et al., 2006; Wahla \& Kirkham, 2008).

When flow velocity increases up to $100 \mathrm{~m}^{3} / \mathrm{s}$, some part of riverbank areas were submerged with excess water from the river in which the stream water pollutants had to accepted the debris, eroded soils, organic wastes, toxic and non-toxic chemicals, microorganisms, and nematodes without any doubts. That is the reason why BOD was low at the time of draining, then, it has been gradually increased until it reached at about $10 \mathrm{~km}$ before entering to urban areas, that is, BOD $2.9 \mathrm{mg} / \mathrm{L}$ Phetchaburi dam (SW1) to increase up to BOD $4.9 \mathrm{mg} / \mathrm{L}$ at (SW2), and going down to SW3. The BOD values at SW3 point were still decreased about $2.5 \mathrm{mg} / \mathrm{L}, 2.2 \mathrm{mg} / \mathrm{L}$ at SW4, 2.4 $\mathrm{mg} / \mathrm{L}$ at SW5, and $2.9 \mathrm{mg} / \mathrm{L}$ at SW6 but it became $1.6 \mathrm{mg} / \mathrm{L}$ at SW7 and going up to $4.4 \mathrm{mg} / \mathrm{L}$ at SW8 as the maximum value because of estuarine effluences Tanji et al 2006, Srigate 2009, Robinson and Maris 1085, and Postel and Richter 2003). However, DO was gradually decreased from Phetchaburi diversion dam to the outlet, only city zone found an increase while BOD decreased since the measuring point SW3 is located at the bridge nearby Big-C Super Market that expected to pollute much more organic waste in streamflow (Penha-Lopes et al., 2011; Mangimbulude et al., 2012). The said condition can encourage some amount of DO for serving the bacterial organic digestion processes that the reason why DO decrease throughout the river of Phetchaburi. It is remarkable for careful observation when flow velocity increased up to $377 \mathrm{~m}^{3} / \mathrm{s}$ that trends of BOD and DO looked the same downslope due to much more rainwater of heavy rainstorm is usually plenty of DO and also increasing BOD in stream water. For this reason, the decrease of DO because it was used for bacterial organic digestion process that made BOD lowering as well but interesting point was on the city zone in terms of urban rainwater in city zone being composed of DO while drastic increases of BOD was occurred by erosion process due to much more excessive rainwater on the ground surface with very less infiltration rate (Cazelles et al., 1991; Loomis et al., 2000; Burnett et al., 2007; Chen et al., 2008; Liu et al., 2009; Chu et al., 2010; LERD, 2012; Mangimbulude et al., 2012; Rakthai, 2012; Kraus et al., 2014).

\subsection{Handling Water for Dilution Process}

Close study on previous water quality analysis in relation to flow measurement and stream pollution in Phetchaburi river from beginning up to the present time, it should be emphasized due to obtain the key productive results as indicated by sensitive indicators of BOD and DO concentration that Phetchaburi diversion dam manager has provided nourishment of Phetchaburi river with running all year round, except for a short time in running dry stream. Pulling apart of streamflow as drained from Phetchaburi diversion dam to the double-crop farmlands has to be carefully considered to have water enough for feeding Phetchaburi river in maintaining the riverine ecosystems all the way to the river mount. Following Chunkao (2008) and Chunkao et al. (1981), watershed as a unit area for water management in terms of water quantity, desirable water quality, and water flow regime in which the irrigation watershed management can be applicable in managing quantity water flow in Phetchaburi River together with governing flow regime. Thus, well-planned management of irrigation watershed could be affected on water yields (water quantity, quality and flow regime) to take in irrigated areas without water shortage even in climatic condition of drought.

Luckily, headwater of Phetchaburi irrigation watershed has been covered with tropical rainforest which is characterized as moist, 12-month rain falling, high amount of rainfall, high rainfall intensity going hand-in-hand with long duration, and less evapotranspiration, and narrow different maximum and minimum temperature. It is astonished in Kaeng Krachan rainforest trees to condition in soils to be friable, more soil porosity, high organic matter content, and deep profile on which they are satisfied for high water holding capacity, that is, absorbing 
much more rainwater before releasing to stream (Baver, 1968; Baver et al., 1972; Chunkao et al., 1981; Linsley et al., 1988; Loomis et al., 2000; Postel \& Richter, 2003; Mathews \& Richter, 2007; Chunkao, 2008). Consequently, the water as kept in soils (three forms: chemical combined water, soil pores, and coating on surface of soil particles) is normally supplied to Kaeng Krachan reservoir without shortage even in very dry period of summer time (Baver, 1968; Baver et al., 1972; Linsley et al., 1988; Chunkao, 2008). The aforesaid statements are brought to emphasize that the failure of dilution process for eliminating stream pollution of Phetchaburi River is depended on handling water of Phetchaburi diversion dam rather than water shortage in Kaeng Krachan reservoir as supply sources. Eventually, keeping Kaeng Krachan National Park green (more 50\% cover) is beyond the handling water at Phetchaburi diversion dam according to support the rainforest soils for increasingly absorbing rainwater before releasing to store in Kaeng Krachan reservoir and following to transfer to Kaeng Krachan diversion dam before providing nourishment of Phetchaburi river with continuous flow (more or less $30 \mathrm{~m} / \mathrm{s}$ ) throughout the estuarine at river mouth.

\section{Conclusion}

An investigation on handling water flow from Phetchaburi diversion dam was concentrated in the relationship between flow velocity control and dilution capacity of stream pollution, especially in the period of water shortage from irrigating much more water to double-crop rice fields and also running dry of stream in summer time. To achieve the target, the stream water quality and streamflow measurement as recorded in previous analysis was taken in in-depth understanding together with updated researches and also study on accidental heavy rainstorm to be included the resulting flash flood in agricultural, city, and estuarine zones. Due to the water quality indicators (BOD, DO, TDS, salinity, $\mathrm{pH}$, temperature, coliform bacteria, fecal bacteria) did not show any differences in decrease and increase tendency, therefore, BOD and DO were selected as the representatives for determining flow and dilution capacity while the water flows all the way from Phetchaburi diversion dam throughout agricultural, city, and estuarine zones. The research results will be concluded as follows:

1) Most of water quality indicators in Phetchaburi river from Phetchaburi diversion dam all the way to all-year-cropping agricultural, dense-populated city/municipals, and estuarine zones were useable for any consumption, except in dry period and the period of taking apart much more water to double-crop fields for growing rice and some other cash crops.

2) An increasing flow velocity from $22.4 \mathrm{~m}^{3} / \mathrm{s}$ to $100 \mathrm{~m}^{3} / \mathrm{s}$ and jumping up to $377 \mathrm{~m}^{3} / \mathrm{s}$ were evidently resulted in high capacity of stream pollution by dilution process but flash floods occurring on riverbanks and the dense-populated communities in downstream areas, particularly municipality of Thayang, Amphoe Muang Phetchaburi, and Ban Laem districts.

3) Although the higher flow velocity, 100 and $377 \mathrm{~m}^{3} / \mathrm{s}$, was shown the better results in dilution processes than less speed, the flash floods impacted on tangible and intangible losses. Therefore, the better capacity of dilution process is recommended to keep flow rate less than $30 \mathrm{~m} / \mathrm{s}$ in dry period and less than $10 \mathrm{~m}^{3} / \mathrm{s}$ in wet period.

4) Well-planned management of forest cover more or less $50 \%$ of irrigation watershed area should be the most probable areal size keep water in soils in order to serve the necessity of water consumption without anytime of shortage.

\section{Acknowledgments}

We are thankful to staffs of The King's Royally Initiative Laem Phak Bia Research and Development Project for their supporting. We are also in debt to The Chaipattana Foundation for conducting and funding this study. We would like to give thanks to the Eco-Science Community Group (ESCG), Department Environmental Science, Faculty of Environment, Kasetsart University for facilitating the personnel and laboratories.

\section{References}

APHA.AWWA.WEF. (1992). Standard methods for the examination of water and wastewater (18th ed.). Washington, DC: American Public Health Association. Retrieved from https://law.resource.org/pub/us/cfr/ibr/002/apha. method.2510.1992.html

AWWA.APWA.WEF. (1999). Standard Method for the Examination of Water and Wastewater (21st ed.). Retrieved from http://www.mwa.co.th/download/file_upload/SMWW_1000-3000.pdf

Baver, L. D. (1968). Soil Physics. John Wiley and Sons Inc., New York.

Baver, L. D., \& Gardner, W. H. (1972). Soil Physics. John Wiley and Sons, Inc., New York.

Burnett, W. C., Wattayakorn, G., Taniguchi, M., Dulaiova, H., Sojisuporn, P., Rungsupa, S., \& Ishitobi, T. (2007). 
Groundwater-derived nutrient inputs to the upper Gulf of Thailand. Continental Shelf Research, 27(2), 176-190. http://dx.doi.org.10.1016/j.csr.2006.09.006

Cazelles, B., Fontvieille, D., \& Chau, N. P. (1991). Self-purification in a lotic ecosystem: a model of dissolved organic carbon and benthic microorganisms dynamics. Ecological Modeling, 58(1-4), 91-117. http://dx.doi.org.10.1016/0304-3800(91)90031-U

Chen, Y., Cheng, J. J., \& Creamer, K. S. (2008). Inhibition of anaerobic digestion process: A review. Bioresource Technology, 99(10), 4044-4064. http://dx.doi.org.10.1016/j.biortech.2007.01.057

Chen, Z. M., Chen, G. Q., Chen, B., Zhou, J. B., Yang, Z. F., \& Zhou, Y. (2009). Net ecosystem services value of wetland: Environmental economic account. Communications in Nonlinear Science Numerical Simulation, 14(6), 2837-2843. http://dx.doi.org.10.1016/j.cnsns.2008.01.021

Chu, A. D., Con, P. M., \& Nguyen, N. K. (2010). Characteristic of urban wastewater in Hanoi City- nutritive value and potential risk in using for agriculture. VNU Journal of Science, Earth Sciences, 26, 42-47. Retrieved from http://www.tapchi.vnu.edu.vn/KHTD_1_10/5.pdf

Chunkao, K. (2008). Principles of Watershed Management. Kasetsart University Publisher, Kasetsart University, Bangkok, Thailand.

Chunkao, K. (2010). Environmental Science (8th ed.). Kasetsart University Publisher, Kasetsart University, Bangkok, Thailand.

Chunkao, K., Nimpee, C., \& Duangmal, K. (2012). The King's initiatives using water hyacinth to remove heavy metals and plant nutrients from wastewater through Bueng Makkasan in Bangkok, Thailand. Ecological Engineering, 39, 40-52. http://dx.doi.org.10.1016/j.ecoleng.2011.09.006

Chunkao, K., Tangtham, Boonyawat, N. S., \& Niyom, W. (1981). 15-Year Summary "Mountainous Research Project". Department of Conservation, Faculty of Forestry, Kasetsart University, Thailand.

Kraus, J. M., Schmidt, T. S., Walters, D. M., Wanty, R. B., Zuelling, R. E., \& Wolf, R. E. (2014). Cross-ecosystem impacts of stream pollution reduce resource and contaminant flux to riparian food webs. Ecological Application, 24(2), 235-243. http://dx.doi.org.10.1890/13-0252.1

LDD. (2011). Report on the land use in Phetchaburi province. Land Development Department, Ministry of Agriculture and Cooperatives, Bangkok, Thailand.

LERD. (1999). Technology for Community Garbage Disposal and Wastewater Treatment by Aquatic Plants. The King's Royally Initiated Laem Phak Bia Environmental Research and Development Project, Laem Phak Bia sub- district, Ban Laem district, Phetchaburi province. Thailand.

LERD. (2000). Science for Garbage Disposal and Wastewater Treatment towards the King's Initiative Project. Technical Papers for 10-Year LERD Seminar, Paper presented at Kasetsart University, 24-25 August 2000. Bangkok, Thailand.

LERD. (2010). Water Quality of Phetchaburi River. The King's Loyally Initiated Laem Phak Bia Environment Research and Development Project, Laem Phak Bia sub-district, Ban Laem district, Phetchaburi province. Bangkok, Thailand.

LERD. (2011). Annual Report on the King's Royally Initiated Laem Phak Bia Environmental Research and Development Project (LERD), Laem Phak Bia sub-district, Ban Laem district, Phetchaburi province, Thailand: Serial numbers in the years of 2005, 2006, 2007, 2008, 2009, and 2011. Bangkok, Thailand.

LERD. (2012). The King's Royally Initiated Laem Phak Bia sub-district, Ban Laem district, Phetchaburi province. Chaipattana Foundation. Bangkok. Thailand.

Linsley, R. K. J., Kohler, M. A., \& Paulhus, J. L. H. (1988). Hydrology for Engineers. McGraw-Hill Book Company. London. UK.

Liu, W. B., \& Chen, D. M. (2009). Spatial impact of organic matters from point sources on stream water quality. Mine Science and Technology, 19(2), 256-261. http://dx.doi.org.10.1016/S1674-5264(09)60049-1

Loomis, J., Kent, P., Strange, L., Fausch, K., \& Covich, A. (2000). Measuring the total economic value of restoring ecosystem services in an impaired river basin: Results from a contingent valuation survey. Ecological Economics, 33(1), 103-117. http://dx.doi.org. PII: S0921-8009(99)00131-7

Mangimbulude, J. C., Straalen, N. M., \& Roling, F. M. (2012). Microbial nitrogen transformation potential in surface run-off leachate from a tropical landfill. Waste Management, 32(1), 77-87. 
http://dx.doi.org.10.1016/j.wasman.2011.07.029

Mathews, R., \& Richter, B. D. (2007). Application of the indicators of hydrologic alteration software in environmental flow-setting. Journal of the American Water Resources Association, 43(6), 1400-1413. http://dx.doi.org.10.1111/j.1752-1688.2007.00099.x

Penha-Lopes, G., Torres, P., Cannicci, S., Narciso, L., \& Paula, J. (2011). Monitoring anthopogenic sewage pollution on mangrove creeks in Southern Mozambique: A test of Palaemen concinnus Dana, 1852 (Palaemonidae) as a biological indicator. Environmental Pollution, 159(2), 636-645. http://dx.doi.org.10.1016/j.envpol.2010.09.029

Postel, S., \& Richter, B. (2003). Rivers for Life: Managing Water for People and Nature. Island Press, Washington, D.C.

Rakthai, S. (2012). Ecosystem Services Value of the Phetchaburi River. Ph.D. Thesis, Graduate School, Karsetsart University, Bangkok, Thailand.

Randall. G., \& Mulla, D. J. (2000). Nitrate nitrogen in surface waters as influenced by climatic conditions and agricultural practices. Journal of Environmental Quality, 30, 337-344. http://dx.doi.org.10.2134/jeq2001.302337x

Robinson, H. D., \& Maris, P. J. (1985). The treatment of leachate from domestic waste sites. Journal of Water Pollution, 57(1), 41-50. Retrieved from http://www.jstor.org/discover/10.2307/25042517

Srigate, J. (2009). Effects of Community Activities to Water Quality in Phetchaburi River, Phetchaburi Province. M.S. Thesis, Graduate School, Kasetsart University. Bangkok, Thailand.

Tanji, Y., Sakai, R., Miyanaga, K., \& Unno, H. (2006). Estimation of the self-purification capacity of biofilm formed in domestic sewer pipes. Biochemical Engineering Journal, 31(1), 96-101. http://dx.doi.org.10.1016/j.bej.2006.05.021

Vagnetti, R., Miana, P., Fablis, M., \& Pavoni, B. (2011). Self-purification ability of a resurgence stream. Chemosphere, 52(10), 1781-1795. http://dx.doi.org.10.1016/S0045-6535(03)00445-4

Valipour, A., Raman, V. K., \& Ghole, V. S. (2009). A new approach in wetland systems for domestic wastewater treatment using Phragmite sp. Ecological Engineering, 35(12), 1797-1803. http://dx.doi.org.10.1016/j.ecoleng.2009.08.004

Wahla, I. H., \& Kirkham, M. B. (2008). Heavy metal displacement in salt-water- irrigated soil during phytoremediation. Environmental Pollution, 155(2), 271-283. http://dx.doi.org.10.1016/j.envpol.2007. 11.020.Epub 2008 Jan 3

Wang, L. K., Vielkind, D., \& Wang, M. H. (1978). Mathematical Models of Dissolved Oxygen Concentration in Fresh Water. Ecological Modelling, 5(2), 115-123. http://dx.doi.org.10.1016/0304-3800(78)90034-0

Wang, M., Zhang, J., Tu, Z., Gao, X., \& Wang, W. (2010). Maintenance of estuarine water quality by mangroves occurs during flood periods: A case study of a subtropical mangrove wetland. Marine Pollution Bulletin, 60(11), 2154-2160. http://dx.doi.org.10.1016/j.marpolbul.2010.07.025

WHO and UNICEF. (2010). Progress on Sanitation and Drinking-water: 2010 Update. Retrieved from http:// www.whqlibdoc.who.int/ publications/ 2010/9789241563956_eng.pdf?ua=1

WHO. (2010). UN-water global annual assessment of sanitation and drinking-water (GLAAS) 2010: targeting resources for better results. Retrieved from http://www.unwater.org/fileadmin/user_upload/unwater_new/docs/UN-Water_GLAAS_2010.pdf

\section{Copyrights}

Copyright for this article is retained by the author(s), with first publication rights granted to the journal.

This is an open-access article distributed under the terms and conditions of the Creative Commons Attribution license (http://creativecommons.org/licenses/by/3.0/). 